\title{
Conidial Germination, Infection Structure Formation, and Early Colony Development of Powdery Mildew on Poinsettia
}

\author{
G. J. Celio and M. K. Hausbeck
}

Department of Botany and Plant Pathology, Michigan State University, East Lansing, 48824-1312.

Accepted for publication 15 November 1997.

\begin{abstract}
Celio, G. J., and Hausbeck, M. K. 1998. Conidial germination, infection structure formation, and early colony development of powdery mildew on poinsettia. Phytopathology 88:105-113.

Powdery mildew disease on poinsettias (Euphorbia pulcherrima) growing in commercial greenhouses was first observed in the United States in 1990 and has become an economically significant problem for poinsettia growers in the Midwest and northern United States since 1992. The temporal development of infection structures produced by conidial germ tubes of the pathogen (Oidium sp.) and the effect of high temperature on their development were investigated using poinsettia leaf disks placed in humidity chambers. Observations were made using light microscopy and

germinated and formed an appressorium within $6 \mathrm{~h}$ of inoculation. Germination over time followed a monomolecular curve $\left(r^{2}=0.77, P \leq\right.$ 0.0001 ). Within $24 \mathrm{~h}$ postinoculation, germinated conidia had formed secondary germ tubes and a haustorium. The percentage of germinated conidia with appressoria and one or more secondary germ tubes increased linearly with time $\left(r^{2}=0.92, P \leq 0.0001\right)$, while the percentage of germinated conidia with appressoria and haustoria increased monomolecularly $\left(r^{2}=0.93, P \leq 0.0001\right)$. Conidia had an ornamented appearance, and all conidiophores had arced basal cells. When the incubation temperature was $30^{\circ} \mathrm{C}$, conidial germination and development of secondary germ tubes and a haustorium were reduced.
\end{abstract} scanning electron microscopy. At $20^{\circ} \mathrm{C}(85 \%$ relative humidity), conidia

Poinsettia (Euphorbia pulcherrima Willd. ex Klotzsch) is a significant crop for Michigan growers, who produce $5 \%$ of all poinsettias (1993 wholesale value of \$9.9 million) in the United States (1). The primary foliar disease of poinsettia has been leaf, stem, and bract blight caused by Botrytis cinerea (24). However, since 1992, powdery mildew disease has become a significant and persistent problem for poinsettia growers in the Midwest and northern United States, although it has also been reported in a number of states outside these areas (M. K. Hausbeck, unpublished data; M. L. Daughtrey, personal communication). The disease was first reported in the United States on poinsettias in $1990(11,25)$ and also by growers in Puerto Rico and Mexico (11).

The pathogen (Oidium sp.) appears on abaxial and adaxial leaf and bract surfaces as discrete, white colonies up to $1.0 \mathrm{~cm}$ in diameter that may coalesce. When colonies initiate on leaf undersides, the disease may not be detected until late in the production cycle, when bracts are infected and plants are unsaleable. However, poinsettias may not exhibit signs of infection until after leaving the production greenhouse, which results in customer dissatisfaction (12).

Still considered a new disease in the United States, little is known about powdery mildew disease on poinsettia. The conidial form of the causal organism is very similar to that of Microsphaera euphorbiae (U. Braun, personal communication), and conidial wall features are consistent with those of pseudoidium anamorphs of Erysiphe section Erysiphe and of Microsphaera and Uncinula (A. J. Inman, personal communication), as well as features of Oidium subgenus Pseudoidium (10). However, in the absence of observed cleistothecia to date, it has been termed simply Oidium sp., the approach we also have taken in this study.

Corresponding author: G. J. Celio; E-mail address: gcelio@arches.uga.edu

Publication no. P-1997-1215-02R

(C) 1998 The American Phytopathological Society
Additional keywords: heat treatment, morphology, time series.
Conidia of this fungus are oval to cylindrical, 15 to $20 \times 25$ to $50 \mu \mathrm{m}$, with a chain of up to nine conidia on a single conidiophore (25). Peak conidial concentrations in the greenhouse atmosphere are associated with a rapid change in temperature, relative humidity $(\mathrm{RH})$, or both, with routine grower activity having little or no effect (36).

Growers who detect powdery mildew disease early in production may eliminate the disease by removing infected leaves and applying appropriate fungicides (21). Although protective and systemic fungicides are effective against the disease $(13,22)$, their cost can reduce growers' profits. Chemical residue and phytotoxicity also may leave treated plants unsaleable. Resistance of cultivars has been investigated $(8,26)$, but all cultivars tested became symptomatic by 31 days after inoculation.

The objectives of this study were to examine early colony development in powdery mildew disease and to establish the time necessary for conidial germination and infection processes on poinsettia foliage under controlled environmental conditions. The response of the pathogen to temperature was also examined. Altering environmental conditions within greenhouses to make conditions unfavorable for Oidium sp. development is a potentially inexpensive method of disease control.

\section{MATERIALS AND METHODS}

Inoculation. Fully expanded leaves were taken from the fourth to seventh node of healthy poinsettias (cv. Freedom Red) maintained in a growth chamber (Sherer-Gillett, Marshall, MI) at $19^{\circ} \mathrm{C}$. Leaf disks were excised with a 1-cm-diameter cork borer, surfacesterilized in a $0.525 \%$ sodium hypochlorite solution for $1 \mathrm{~min}$, rinsed in sterile distilled water $\left(\mathrm{dH}_{2} 0\right)$, and dried under a laminar flow hood.

Inoculum of Oidium sp. (Michigan State University Herbarium, East Lansing, accession \#361714, Mary Hausbeck 01) was produced on infected poinsettias (cv. Freedom Red) maintained in a growth chamber (Sherer-Gillett) at $20^{\circ} \mathrm{C}$, high humidity $(>70 \%)$, 
and a 12-h photoperiod. To ensure uniform age and viability, conidia were dislodged 3 to 5 days before inoculation by shaking plants at the base of their stems to promote growth of new conidia. Leaf disks were inoculated by using a plastic-bristle paintbrush to brush conidia off of infected leaves $4 \mathrm{~cm}$ above the disks. Inoculated leaf disks were placed abaxial surface up on a $7-\mathrm{cm}-$ diameter piece of water agar $(20 \mathrm{~g} /$ liter $)(9,20)$ suspended by a plastic mesh grid $(1.7$ squares per $\mathrm{cm})$ in a glass humidity chamber (mason jar, $476 \mathrm{ml}$ ) containing $100 \mathrm{ml}$ of a saturated $\mathrm{KCl}$ salt solution to maintain 82 to $85 \%$ RH (14).

Conidial germination and infection process. Six humidity chambers, each containing eight inoculated leaf disks, were placed in an incubator (Forma Scientific, Marietta, $\mathrm{OH}$ ) at $20^{\circ} \mathrm{C}$ in continuous light. One chamber was removed 2, 6, 12, 24, 36, and $48 \mathrm{~h}$ after inoculation. Four disks within each chamber were examined under a light microscope (Lietz Laborlux S; Leica USA, Deerfield, IL) at $\times 400$ to $\times 1,000$, the remaining four under a scanning electron microscope (SEM). All conidia present on the disks (maximum of 100) were counted using light microscopy and observed for the presence of germ tubes, appressoria, and haustoria. Germination was defined as a conidium having a primary germ tube equal in length to at least half the width of the conidium (29). A randomized complete block design was used. The experiment was conducted three times, with each experiment considered a block for statistical analysis. Data on haustorium formation were only taken for two experiments. Linear, exponential, monomolecular, logarithmic, and Gompertz growth models were tested for fit to percentages over time using a linear regression procedure of SAS (SAS Institute, Cary, NC). The best-fit models were chosen based on comparisons of recalculated $r^{2}$ values and mean square errors.

Early colony development. Healthy poinsettias (cv. Freedom Red) were placed in a $19^{\circ} \mathrm{C}$ growth chamber (Sherer-Gillett) containing infected poinsettias (cv. Freedom Red). Inoculation occurred by shaking infected plants at the base of their stems to dislodge conidia within the growth chamber. Six leaf disks with one or more sporulating colonies at least 2 weeks old were excised
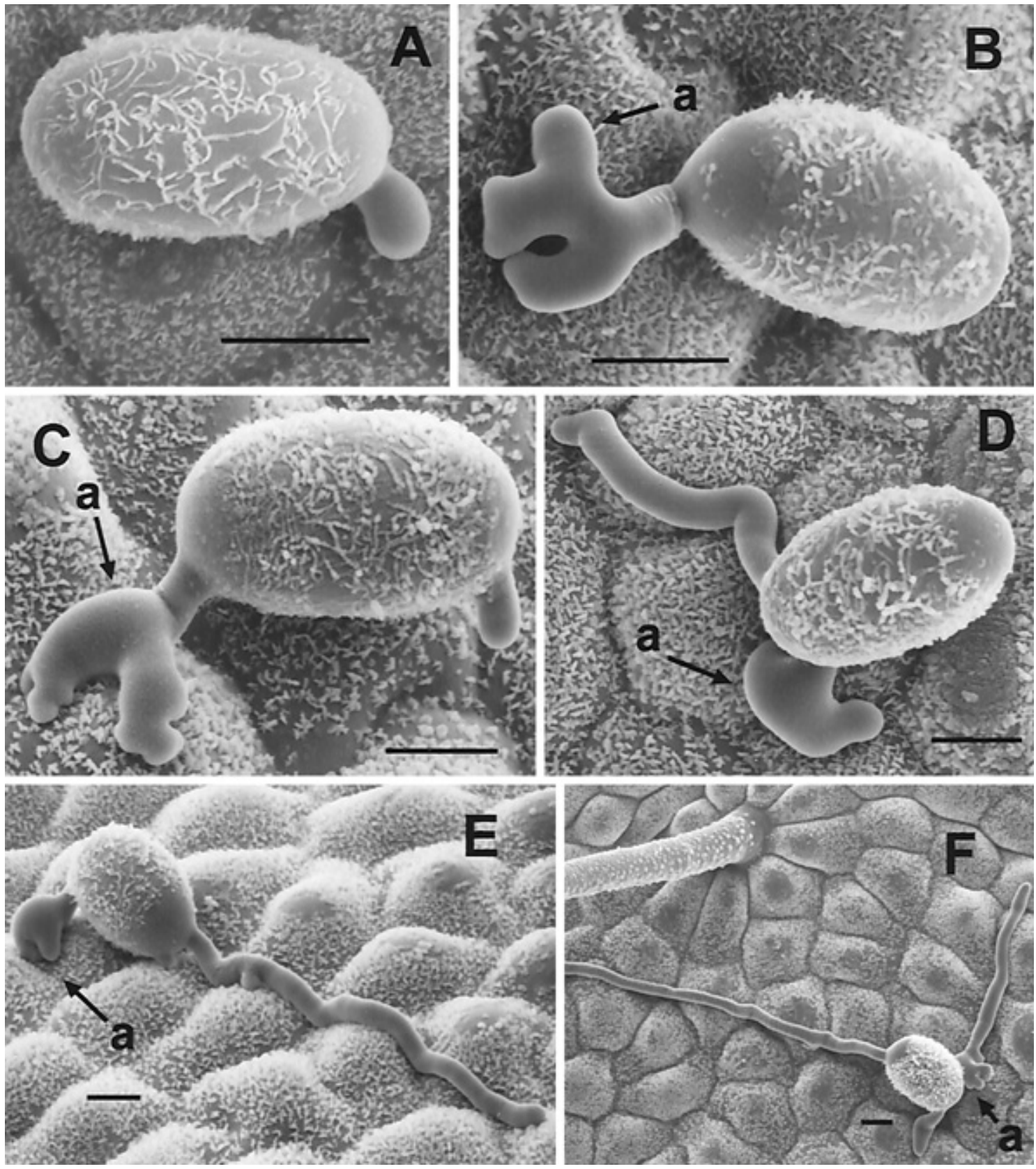

Fig. 1. Scanning electron micrographs of germinating conidia of Oidium sp. (\#361714) on poinsettia leaf disks after A, 2; B, 6; C, 12; D, 24; E, 36; and F, 48 h of incubation at $20^{\circ} \mathrm{C}$. Bars $=10 \mu \mathrm{m}$. 
from fourth to seventh node leaves of infected poinsettias and observed using a SEM.

Response to temperature. Four humidity chambers, each containing four inoculated leaf disks, were placed in a $20^{\circ} \mathrm{C}$ incubator (Forma Scientific), and a duplicate set was placed in a $30^{\circ} \mathrm{C}$ water bath. One chamber was removed from each temperature treatment 24 , 48,72 , and $96 \mathrm{~h}$ after inoculation, and disks were examined using light microscopy. All conidia present on the disks (maximum of 100) were counted, and the presence of germ tubes, appressoria, and haustoria was noted. A factorial experiment was conducted using a splitsplit plot design. The main split was for temperatures, and temperature was split for four sampling times. This experiment was conducted three times, with each experiment considered a replicate. Data on haustorium formation were only taken for two replications.
Light microscopy. Leaf disks were fixed by placing them on filter paper saturated with a formalin/alcohol/acetic acid solution $(1: 18: 1 \mathrm{vol} / \mathrm{vol} / \mathrm{vol})$ in a plastic petri dish sealed with Parafilm (American National Can, Greenwich, CT) for 2 h. Disks were cleared for 42 to $48 \mathrm{~h}$ in a solution consisting of chloral hydrate (200 g), $\mathrm{dH}_{2} \mathrm{O}(80 \mathrm{ml})$, ethanol $(250 \mathrm{ml})$, and four drops of Tween20. Disks were preserved in scintillation vials containing $4 \mathrm{ml}$ of lactophenol solution ( $20 \mathrm{~g}$ of phenol, $20 \mathrm{ml}$ of lactic acid, $40 \mathrm{~g}$ of glycerin, and $20 \mathrm{ml}$ of water) until stained using cotton blue stain in lactophenol solution $(100 \mathrm{ml}$ of lactophenol, $1 \mathrm{ml}$ of $1 \%$ aqueous cotton blue, and $20 \mathrm{ml}$ of glacial acetic acid) and then mounted in glycerol for observation.

Electron microscopy. After incubation, leaf disks were trimmed and mounted on copper specimen stubs using Tissue-Tek (Ames
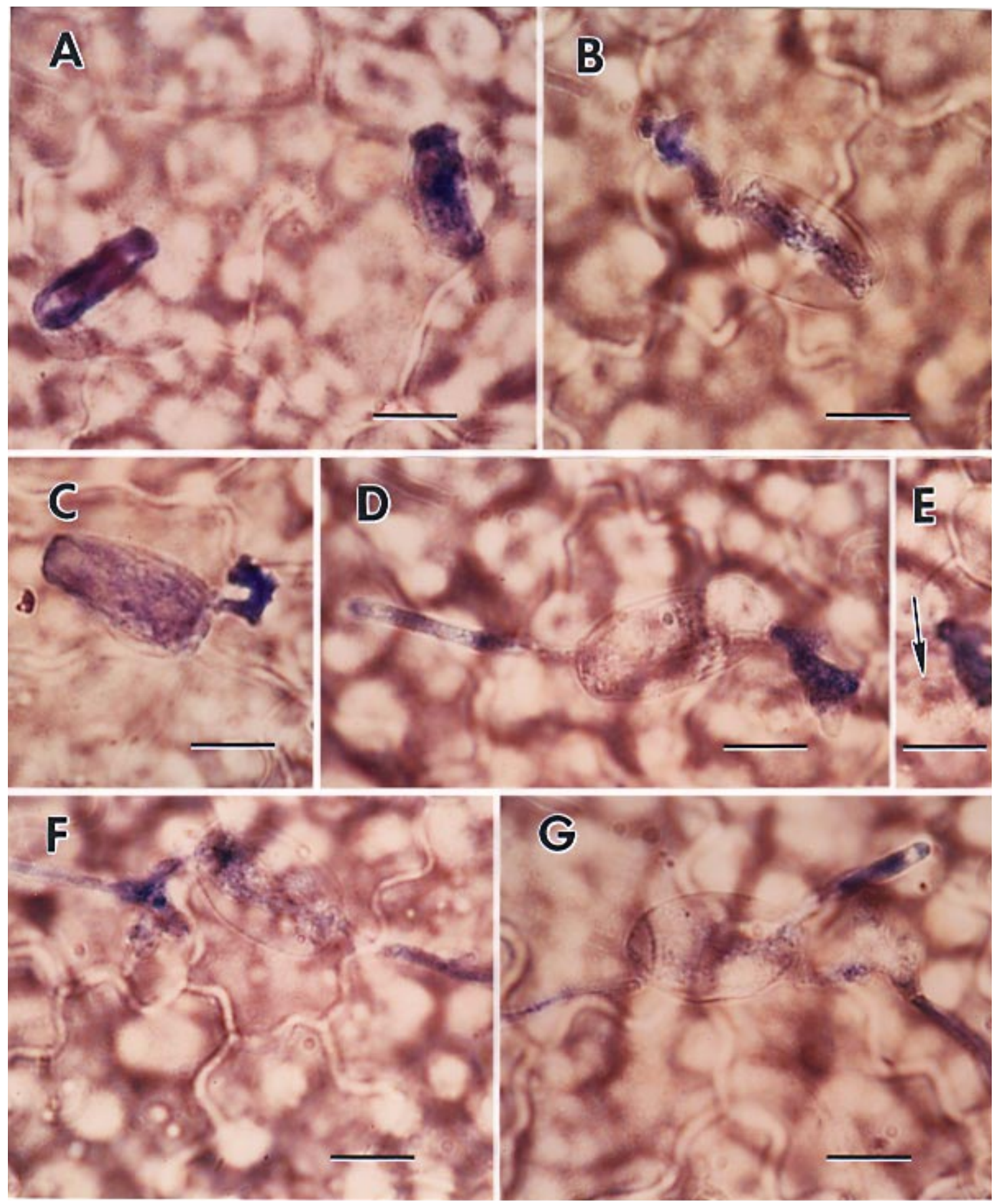

Fig. 2. Light micrographs of germinating conidia of Oidium sp. (\#361714) on poinsettia leaf disks after A, 2; B, 6; C, 12; D, 24 (E, detail of haustorium); F, 36; and $\mathbf{G}, 48 \mathrm{~h}$ of incubation at $20^{\circ} \mathrm{C}$. Bars $=10 \mu \mathrm{m}$. 
Division, Miles Lab, Inc., Elkhart, IN) and then processed for observation using a sputter cryo system (Emscope SP2000; Emscope, Ashford, Kent, England). Mounted specimens were plunged into liquid nitrogen slush for $30 \mathrm{~s}$ and then transferred under vacuum to the specimen chamber of a SEM (JSM-35CF; JEOL, Peabody, MA) fitted with a cold stage attachment. Samples were thermally etched at $-65^{\circ} \mathrm{C}$ to remove ice crystals and then transferred under vacuum to the work chamber and sputter-coated with gold. Observations were made at an accelerating voltage of $10 \mathrm{kV}$ and a specimen temperature of $-145^{\circ} \mathrm{C}$.

\section{RESULTS}

Leaf disks used in this study remained hydrated and viable for the duration of the observations. Although conidia were displaced from the leaf disk surface during fixation, the majority of disks had a minimum of 50 conidia.

SEM observations (Fig. 1A) revealed that primary germ tubes were initiated within $2 \mathrm{~h}$ of inoculation. However, germination as defined in this study (a conidium displaying a primary germ tube that was equal in length to at least half the width of the conidium) for light microscopic observations was not observed until $6 \mathrm{~h}$ after inoculation (31.7\%) (Fig. 2A and B). Conidial germination peaked $(76.0 \%) 36 \mathrm{~h}$ after inoculation (Fig. 3A). Conidial germination over time was best described by a monomolecular model. The $r^{2}$ for regression of conidial germination against time was $0.77(P \leq$ $0.0001)$ and was described by the equation $y=1-(0.79)^{-0.03(x)}$. When viewed using a SEM, conidia appeared to have a rough texture except at their rounded ends (Fig. 1A to F).

Appressoria that arose from primary germ tubes appeared slightly lobed to lobed (Figs. 1B to F and $2 \mathrm{~B}$ to $\mathrm{G}$ ) and were observed on $90.0 \%$ of germinated conidia $6 \mathrm{~h}$ after inoculation (Fig. 3B). At the last observation (48 h), $99.0 \%$ of the germinated conidia had formed an appressorium.

The emergence of a germ tube from a primary appressorium was common (Figs. $1 \mathrm{~F}$ and $2 \mathrm{~F}$ and $\mathrm{G}$ ), while branching of germ tubes was rare. At $24 \mathrm{~h}$ after inoculation, $40 \%$ of germinated conidia displayed one or more secondary germ tubes. At the last ob-
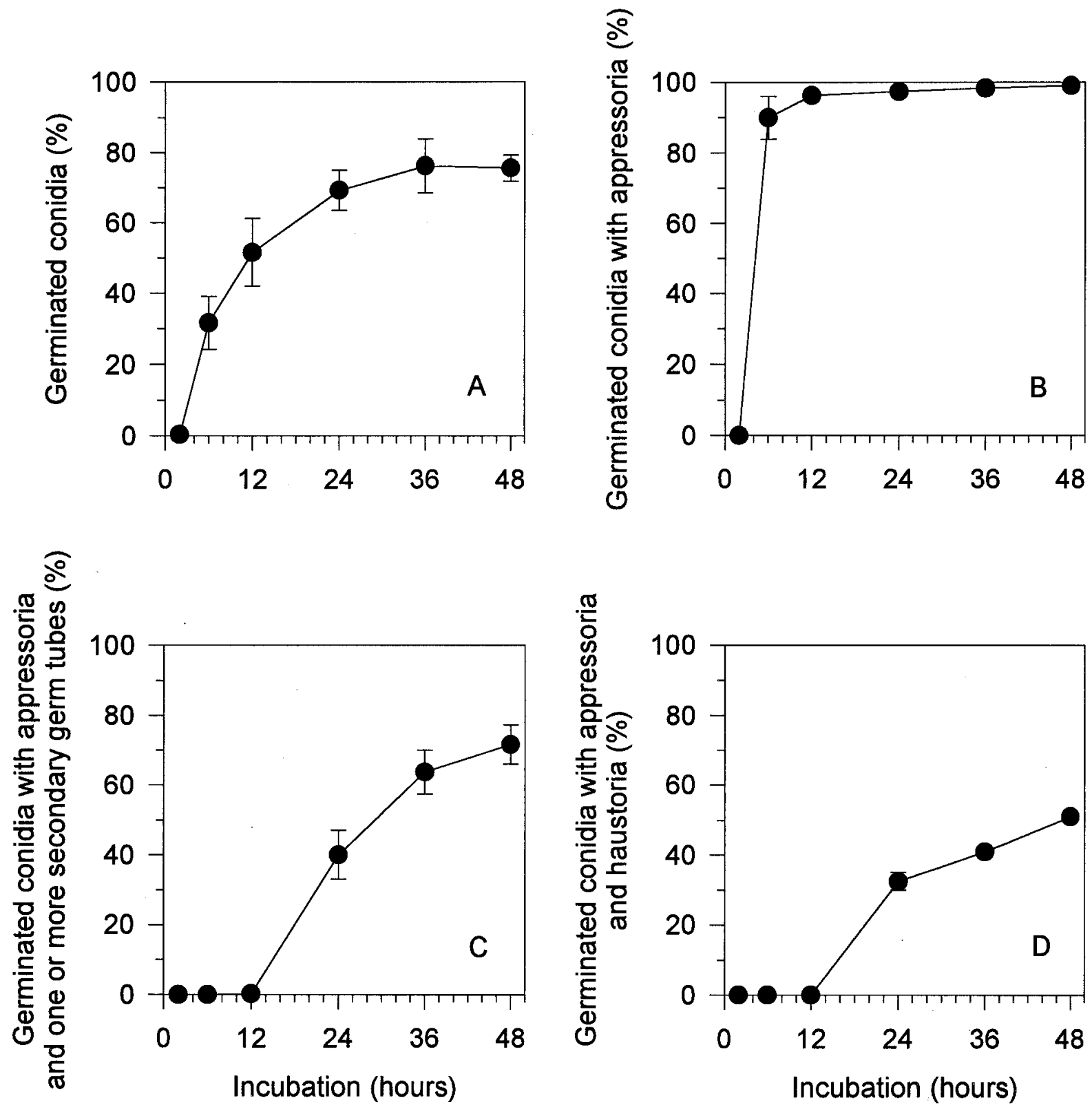

Fig. 3. Conidium germination, appressorium formation, and haustorium formation by Oidium sp. (\#361714) at $20^{\circ} \mathrm{C}$. A, Germinated conidia; B, germinated conidia with appressoria; $\mathbf{C}$, germinated conidia with appressoria and one or more secondary germ tubes; and $\mathbf{D}$, germinated conidia with appressoria and haustoria. Data points represent means, and error bars correspond to standard errors of the means. 
servation $(48 \mathrm{~h}), 71.7 \%$ of germinated conidia whose primary germ tubes had formed appressoria also had formed one or more secondary germ tubes. The production of secondary germ tubes increased linearly with time (Fig. 3C). The $r^{2}$ for regression of the percentage of germinated conidia with an appressorium and one or more secondary germ tubes against time was $0.92(P \leq 0.0001)$ and was described by the equation $y=-0.09+0.02(x)$.

Haustoria appeared as globose structures with the haustorial sac typically visible (Fig. 2E). Within 24 and $48 \mathrm{~h}$ after inoculation, 32.5 and $51.0 \%$, respectively, of germinated conidia had an appressorium and a haustorium (Fig. 3D). The increase in the percentage of germinated conidia with an appressorium and a haustorium over time fit a monomolecular model of growth. The $r^{2}$ for regression of the percentage of germinated conidia with an appressorium and a haustorium was $0.93(P \leq 0.0001)$ and was described by the equation $y=1-(1.06)^{-0.01(x)}$.

In colonies 2 weeks old and older on whole plants, germ tubes formed from up to six positions on conidia (Fig. 4A). Hyphae maintained directional growth from the point of their initiation following the contours of the host surface (Fig. 4A and B), and branching hyphae grew in a direction obtuse to the line of directional hyphal growth. Lateral appressoria that formed off of hyphae developed singly and in pairs opposite one another, appearing slightly lobed to lobed (Fig. 4A and C). Cuticle degradation was visible beneath secondary appressoria (Fig. 4C). Conidiophores displayed an arced basal cell (Fig. 4A, D, and E) and consisted of up to four cells, including the developing conidium. Thin, slightly spiraling parallel longitudinal ridges were occasionally visible on the cell directly adjacent to the conidium (Fig. 4A and E).

Conidial germination on leaf disks was significantly reduced when the incubation temperature was $30^{\circ} \mathrm{C}(\leq 64 \%)$ versus $20^{\circ} \mathrm{C}$ ( $\geq 80 \%$ ), although incidence of appressorium formation from germinated conidia was not significantly affected (Figs. 5A and B and 6). Significantly more conidia were shriveled (Fig. 6J) when incubated at $30^{\circ} \mathrm{C}(29 \%)$ versus $20^{\circ} \mathrm{C}(9 \%)$ for $96 \mathrm{~h}$. Incubating conidia at $30^{\circ} \mathrm{C}$ significantly limited the incidence of secondary
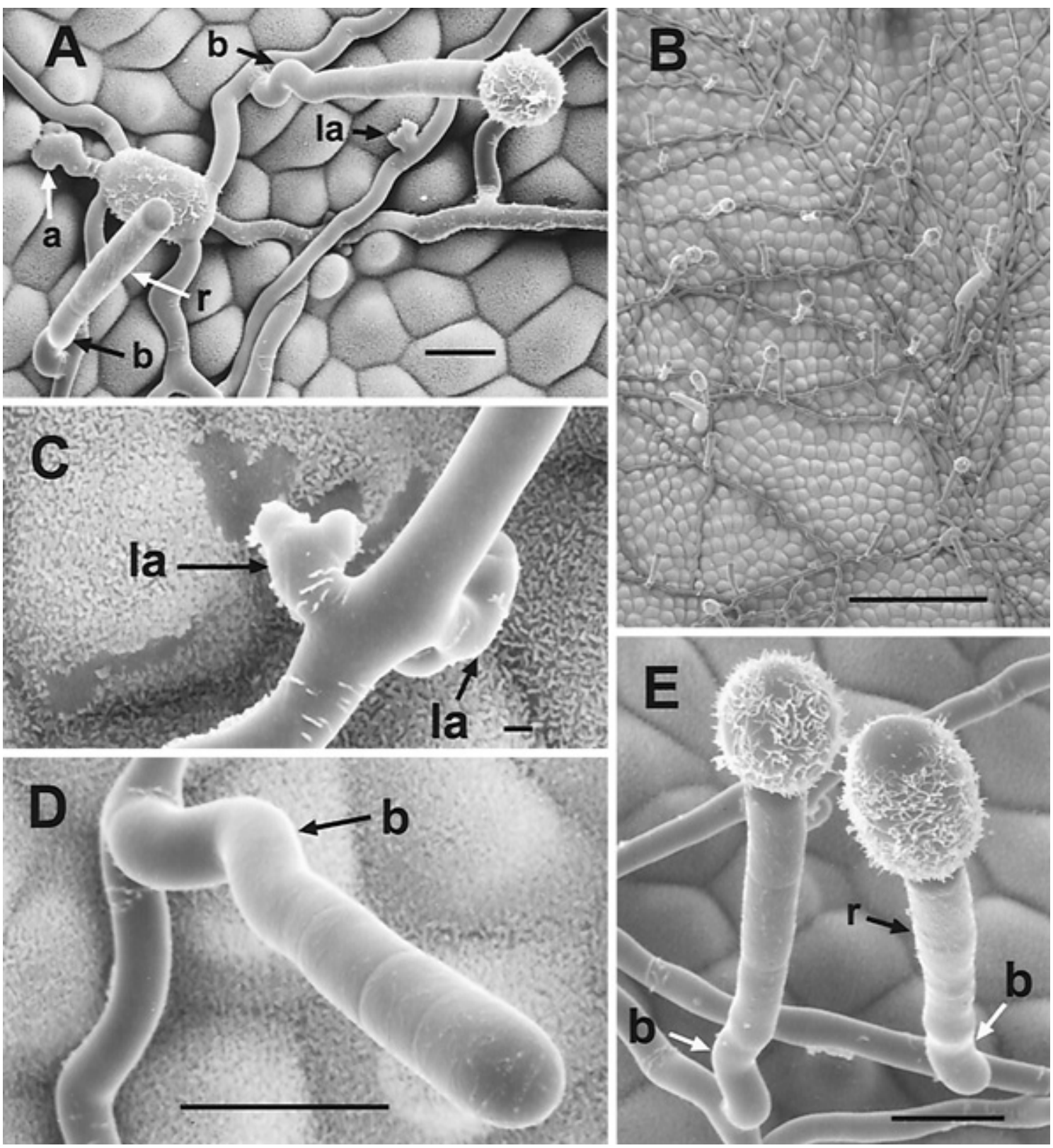

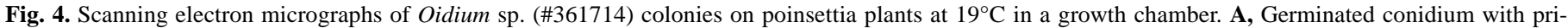

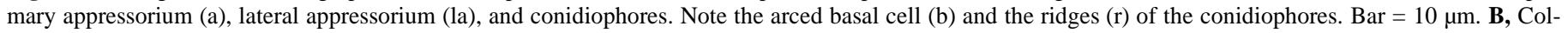

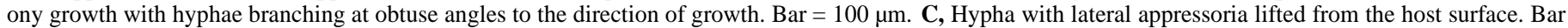
$=1 \mu \mathrm{m}$. D, Young conidiophore with arced basal cell. Bar $=10 \mu \mathrm{m}$. E, Mature conidiophores. Note the ridges on the right-hand conidiophore. Bar $=10 \mu \mathrm{m}$. 
germ tube formation on germinated conidia $(\leq 1 \%)$ compared with incubating conidia at $20^{\circ} \mathrm{C}(\geq 53 \%)$ (Figs. 5C and 6). Similarly, haustorium development was significantly limited by the $30^{\circ} \mathrm{C}$ incubation treatment $(<4 \%)$ compared with the $20^{\circ} \mathrm{C}$ incubation treatment $(>32 \%)$ (Fig. 5D).

\section{DISCUSSION}

Conidial germination and infection processes of Oidium sp. (\#361714) were quantified on poinsettia foliage. At $20^{\circ} \mathrm{C}(85 \%$ $\mathrm{RH})$, conidia germinated and formed an appressorium within $6 \mathrm{~h}$ of inoculation, roughly similar to the timing reported for other powdery mildews. Conidial germination for Erysiphe graminis $\mathrm{f}$. sp. hordei and E. pisi occurs within $2 \mathrm{~h}$ after inoculation $(2,37)$, after $4 \mathrm{~h}$ for Sphaerotheca macularis f. sp. fragariae (33), between 2 and 4 h for S. panosa (34), and within a few hours for $E$. trifolii (7). After germination, the primary germ tube of Oidium sp. (\#361714) on poinsettia forms the primary appressorium. In con- trast, E. graminis f. sp. hordei forms a primary germ tube that terminates a short distance from the conidium, and 6 to $10 \mathrm{~h}$ after inoculation, the secondary germ tube forms the primary appressorium (2).

Within 24 h after inoculation, conidia of Oidium sp. (\#361714) had formed one or more secondary germ tubes and a globose haustorium. While penetrations pegs emerging from appressoria were not easily visible, the formation of a haustorium and elongating secondary germ tubes may be considered evidence that the fungus had established a functional relationship with the host (16). Within 11 to $13 \mathrm{~h}$ after inoculation, E. graminis f. sp. hordei penetrates the epidermal host cell via a combination of chemical and mechanical means $(2,28)$, after which this pathogen begins to produce a haustorium.

In this study, the convoluted sinuous ridges of the conidia of Oidium sp. (\#361714) may be natural ornamentation or possibly due to secreted extracellular material whose appearance may be slightly exaggerated because of the gold coating. A thin layer of
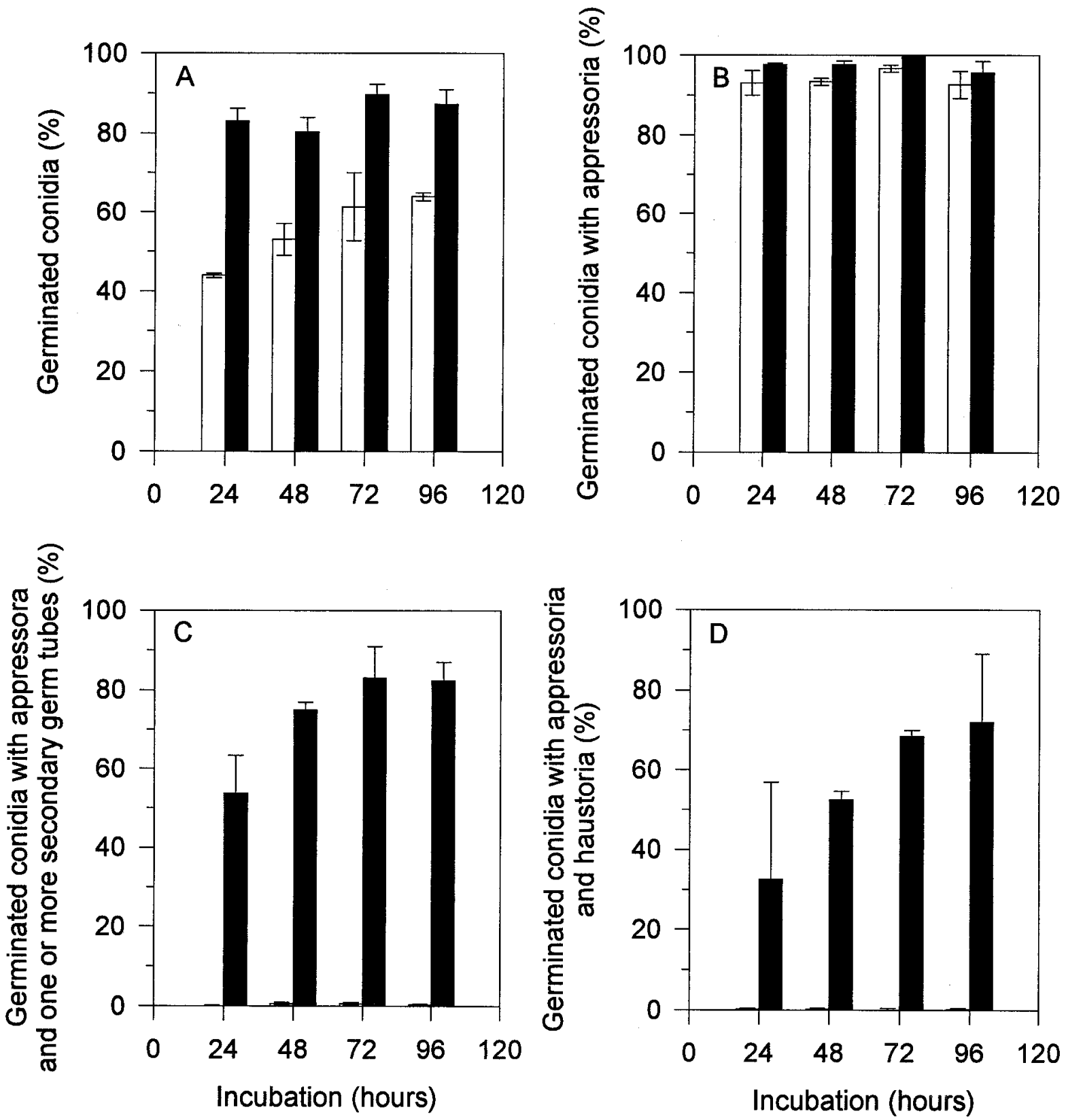

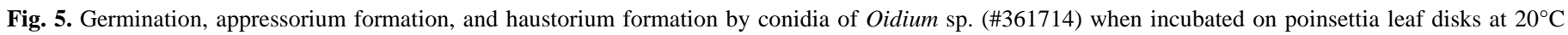

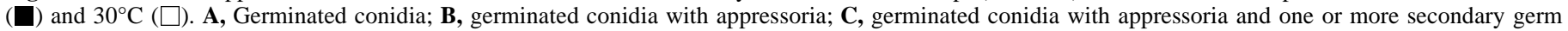
tubes; and $\mathbf{D}$, germinated conidia with appressoria and haustoria. Data bars represent means, and error bars correspond to standard errors of the means. 

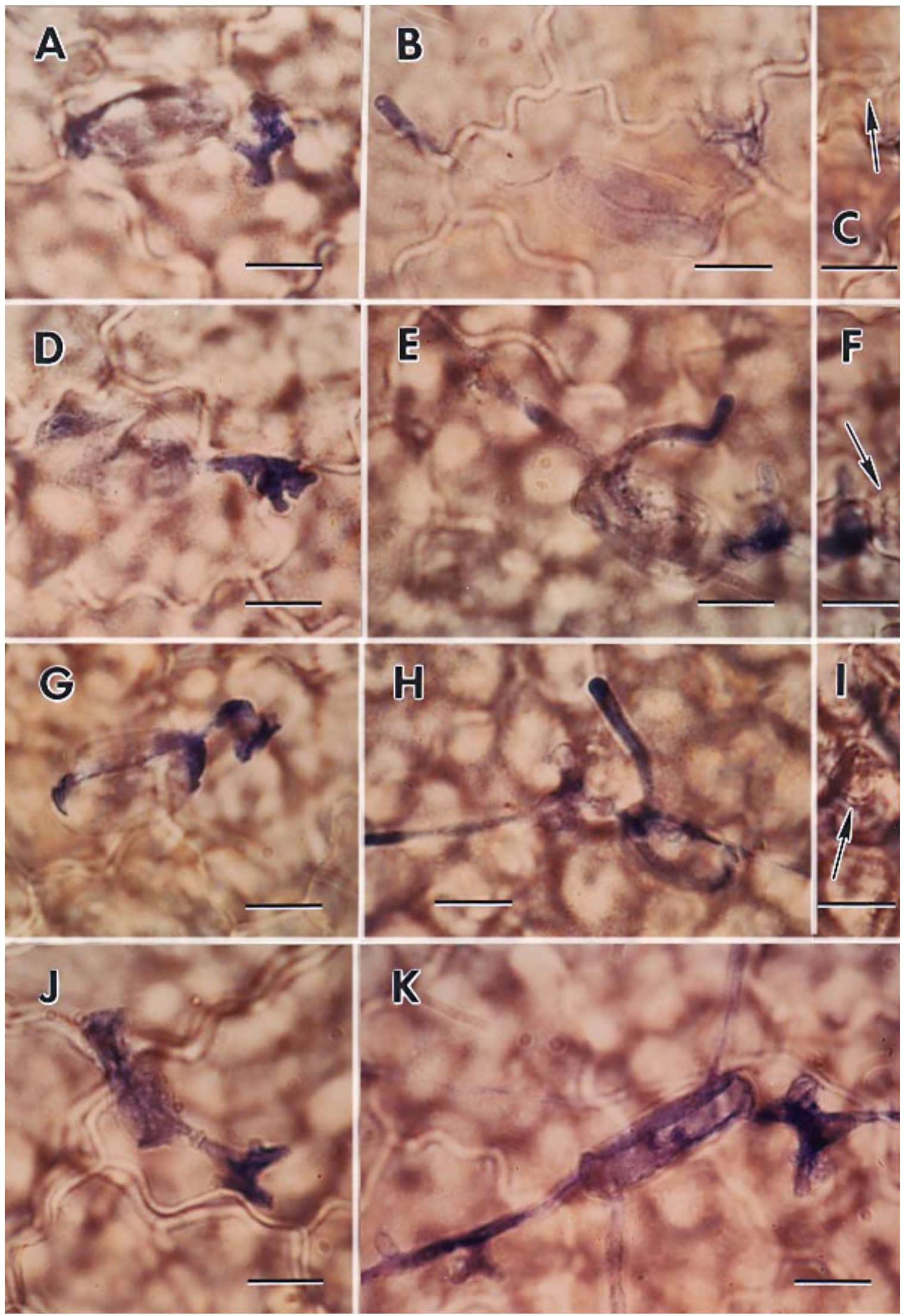

Fig. 6. Light micrographs of germinating conidia of Oidium sp. (\#361714) on poinsettia leaf disks after $\mathbf{A}, 24 \mathrm{~h}$ of incubation at $30^{\circ} \mathrm{C}$ and $\mathbf{B}$, at $20^{\circ} \mathrm{C}(\mathbf{C}$, detail of haustorium from $\mathbf{B}) ; \mathbf{D}, 48 \mathrm{~h}$ of incubation at $30^{\circ} \mathrm{C}$ and $\mathbf{E}$, at $20^{\circ} \mathrm{C}(\mathbf{F}$, detail of haustorium from $\mathbf{E}) ; \mathbf{G}, 72 \mathrm{~h}$ of incubation at $30^{\circ} \mathrm{C}$ and $\mathbf{H}$, at $20^{\circ} \mathrm{C}(\mathbf{I}$, detail of haustorium from $\mathbf{H}$ ); and $\mathbf{J}, 96 \mathrm{~h}$ of incubation at $30^{\circ} \mathrm{C}$ and $\mathbf{K}$, at $20^{\circ} \mathrm{C}$. Bars $=10 \mu \mathrm{m}$. 
extracellular material previously has been demonstrated on the ungerminated conidia of the powdery mildew fungus Uncinuliella australiana (31). This material may be responsible for preparation of the infection court, adhesion of the powdery mildew conidia to host surfaces, or both. Within $5 \mathrm{~min}$ after inoculation, a conidium of E. graminis f. sp. hordei has been shown to release a liquid exudate containing esterase and other enzymes that dissolve cuticular waxes. Nicholson and Kunoh (32) have suggested that the exudate changes the host surface from hydrophobic to hydrophilic, which is required for initiation of infection processes. After the release of this exudate, the conidium surface also becomes hydrophilic, a change necessary for conidia to produce appressoria. Exudate spreading from the conidium to the host surface was not observed in our study. However, it is likely that enzymatic activity occurred during the infection process, because surface waxes beneath the appressoria were apparently dissolved (Fig. 4B).

In this study, thin ridges were observed on the subterminal cells of some conidiophores. Ridges were not visible on all conidiophores observed and may be the result of extracellular material deposited on cells as they grow. Braun (4) described conidial surfaces varying from smooth, faintly rough, or verrucose to strongly verrucose. Ridges on powdery mildew conidia have been reported on 15 members of Erysiphaceae collected from northern New Zealand (19), U. australiana (31), E. pisi (37), E. galeopsidis (17), and $O$. bauhiniae and $O$. buddlejae (18). Using the SEM, Cook et al. (10) observed previously undescribed conidial surface features of numerous powdery mildew anamorphs and proposed a revision/ clarification of Erysiphaceae incorporating these characteristics.

The arced basal cell of powdery mildew on poinsettia appears to be a unique morphological feature. Conidiophore basal cells of various powdery mildew genera have been observed to be straight, bulbous, or twisted (5). Though the anamorph appears very similar to $M$. euphorbiae (U. Braun, personal communication), the monograph of M. euphorbiae was described from dried specimens, and conclusions based on comparisons of basal cells are uncertain.

In this study, conidial germination was reduced, and development of secondary germ tubes and a haustorium was severely limited when incubation temperatures were $30^{\circ} \mathrm{C}$ compared with $20^{\circ} \mathrm{C}$. Optimal temperatures reported for other powdery mildew fungi are, in general, lower $\left(21^{\circ} \mathrm{C}\right)$ than those for other plant pathogens (39), with germination declining sharply at or just above $30^{\circ} \mathrm{C}(6)$. E. graminis on wheat and barley grows slowly above $25^{\circ} \mathrm{C}(3)$. Quinn and Powell (35) determined that temperatures of $28^{\circ} \mathrm{C}$ or above were not conducive to hyphal growth and sporulation of $O$. begoniae, the causal agent of powdery mildew of begonia.

Typically, powdery mildew disease on poinsettia does not increase in incidence or severity during the summer in the Midwest (G. J. Celio and M. K. Hausbeck, unpublished data) and northeast United States $(12,27)$. This may be a result of the frequent high temperatures $\left(\geq 30^{\circ} \mathrm{C}\right)$ in greenhouses during this time of year negatively affecting conidial germination and formation of haustoria, thereby slowing or stopping disease development.

In addition to temperature, $\mathrm{RH}$ is an important variable in conidial germination, with the optimum temperature decreasing as moisture stress increases $(23,30)$. In this study, the RH level used for incubation was optimal for germination of powdery mildew conidia on poinsettias (20). It is likely, therefore, that incubation at $30^{\circ} \mathrm{C}$ and RH levels below $85 \%$ would reduce conidial germination below that observed in this study.

Temperature manipulation may be a useful tool in managing powdery mildew on poinsettia. Germination was significantly reduced when conidia were exposed to $30^{\circ} \mathrm{C}$. Although formation of appressoria from germinated conidia was not affected by the $30^{\circ} \mathrm{C}$ heat treatment, development of germ tubes and haustoria was halted and shriveling of conidia was observed. Quinn and Powell (35) utilized high temperature treatments to manage $O$. begoniae on begonia and determined that $32^{\circ} \mathrm{C}$ for 6 days was eradicative.
Heat treatments $\left(\geq 40^{\circ} \mathrm{C}\right)$ have also been used effectively to eradicate E. polygoni on bean (38). However, high temperatures delay flowering and promote vegetative growth in poinsettia (15). High temperature eradicative treatments might be feasible when vegetative growth is desired such as during stock plant production or following rooting of cuttings. It may be advantageous for rooted cuttings to be exposed to a high temperature eradicative treatment since the plant size is small, requiring treatment of a much smaller area than if treating larger stock plants. While these treatments would not be helpful in a situation in which reinoculation is possible, it may be helpful in situations in which propagators are interested in treating rooted cuttings prior to shipment to insure that the poinsettia cuttings are free of the powdery mildew pathogen. Though it is unlikely that heat treatments can be used alone, there may be the potential to incorporate temperature manipulation with scouting and fungicide applications to further reduce growers' powdery mildew management costs.

\section{ACKNOWLEDGMENTS}

This study was supported by funding from the American Floral Endowment and Paul Ecke Ranch. We thank U. Braun and A. Inman for taxonomic suggestions, S. Ries and K. Stevenson for help with statistics, and M. Daughtrey, T. Wallace, J. Clevinger, and C. Clevinger for generously providing inoculum and plant material.

\section{LITERATURE CITED}

1. Agricultural Statistics Board. 1994. Floriculture Crops: 1993 Summary. U.S. Dep. Agric., Natl. Agric. Stat. Serv., Agric. Stat. Board, Washington, DC.

2. Aist, J. R., and Bushnell, W. R. 1991. Invasion of plants by powdery mildew fungi, and cellular mechanisms of resistance. Pages 321-345 in: The Fungal Spore and Disease Initiation in Plants and Animals. Plenum Press, New York.

3. Bainbridge, A. 1974. Effect of nitrogen nutrition of the host on barley powdery mildew. Plant Pathol. 23:160-161.

4. Braun, U. 1987. A Monograph of the Erysiphales (Powdery Mildews). J. Cramer, Berlin.

5. Braun, U. 1995. The Powdery Mildews (Erysiphales) of Europe. Gustav Fischer Verlag, New York.

6. Butt, D. J. 1978. Epidemiology of powdery mildews. Pages 51-81 in: The Powdery Mildews. D. M. Spencer, ed. Academic Press, New York.

7. Carr, A. J. H. 1971. Herbage legumes. Pages 254-271 in: Diseases of Crop Plants. J. H. Western, ed. Macmillan, London.

8. Celio, G. J., and Hausbeck, M. K. 1997. Evaluation of poinsettia cultivars for susceptibility to powdery mildew. HortScience 32(2):259-261

9. Cohen, R. 1993. A leaf disk assay for detection of resistance of melons to Sphaerotheca fuliginea race 1. Plant Dis. 77:513-517.

10. Cook, R. T. A., Inman, A. J., and Billings, C. 1997. Identification and classification of powdery mildew anamorphs using light and scanning microscopy and host range data. Mycol. Res. 101:975-1002.

11. Daughtrey, M. L., and Hall, J. 1992. Powdery mildew: A new threat to your poinsettia crop. Grower Talks, Sept., pp. 23-31.

12. Daughtrey, M. L., and Macksel, M. T. 1994. Occurrence and control of powdery mildew on poinsettias in U.S. greenhouses. (Abstr.) Phytopathology 84:543.

13. Daughtrey, M. L., and Macksel, M. 1995. Efficacy of fungicides for control of powdery mildew on poinsettia, 1993. Fungicide Nematicide Tests 50:395.

14. Dhingra, O. D., and Sinclair, J. B. 1985. Appendix C. Solutions to maintain a constant humidity in a closed atmosphere. Pages 319-325 in: Basic Plant Pathology Methods. CRC Press, Boca Raton, FL.

15. Ecke, P., Jr., Matkin, O. A., and Hartley, D. E. 1990. The Poinsettia Manual. Paul Ecke Poinsettias, Encinitas, CA.

16. Ellingboe, A. H. 1972. Genetics and physiology of primary infection by Erysiphe graminis. Phytopathology 62:401-406.

17. Gorter, G. J. M. A. 1987. Relevance of conidial surface structure for identifying Erysiphe galeopsidis DC. S. Afr. J. Sci. 83:112-114.

18. Gorter, G. J. M. A., and Eicker, A. 1985. Two previously undescribed Oidium species from South Africa. Mycotaxon 22:39-42.

19. Hammett, K. R. W. 1977. Taxonomy of Erysiphaceae in New Zealand. N.Z. J. Bot. 15:687-711

20. Hausbeck, M. K., and Kalishek, J. 1994. Influence of temperature and relative humidity on germination of conidia of Oidium spp. on poinset- 
tia. (Abstr.) Phytopathology 84:1085.

21. Hausbeck, M. K., Kalishek, J., Daughtrey, M., and Barnes, L. 1994. Keep the colonies at bay (part 1). Greenhouse Grower 12(9):45-48.

22. Hausbeck, M. K., and Kusnier, J. J., III. 1996. Evaluation of fungicides for the control of powdery mildew of poinsettia, 1994. Fungicide Nematicide Tests 51:398.

23. Hewitt, H. G. 1974. Conidial germination in Microsphaera alphitoides. Trans. Br. Mycol. Soc. 63:587-589.

24. Jones, R. K., and Strider, D. L. 1985. Bedding plants. Pages 409-422 in: Diseases of Floral Crops. Vol. 1. D. L. Strider, ed. Praeger Publishers, New York.

25. Kim, S. H., and Olson, T. N. 1994. Morphology of powdery mildew on poinsettias. (Abstr.) Phytopathology 84:544.

26. Kim, S. H., Olson, T. N., and Michael, A. H. 1995. Susceptibility of poinsettia cultivars to powdery mildew. (Abstr.) Phytopathology 85:1171.

27. Kim, S. H., Olson, T. N., and Portmann, C. E. 1995. Recurrence of powdery mildew on over-summered asymptomatic poinsettias. (Abstr.) Phytopathology 85:1171.

28. Köller, W. 1991. The plant cuticle: A barrier to be overcome by fungal plant pathogens. Pages 219-246 in: The Fungal Spore and Disease Initiation in Plants and Animals. G. T. Cole and H. C. Hoch, eds. Plenum Press, New York.

29. Lacy, M. L. 1994. Influence of wetness periods on infection of celery by Septoria apiicola and use in timing sprays for control. Plant Dis. 78:975-979.
30. Manners, J. G., and Hossain, S. M. M. 1963. Effects of temperature and humidity on conidial germination in Erysiphe graminis. Trans. Br. Mycol. Soc. 46:225-234.

31. Mims, C. W., Liljebjelke, K. A., and Richardson, E. A. 1995. Surface morphology, wall structure, and initial adhesion of conidia of the powdery mildew fungus Uncinuliella australiana. Phytopathology 85:352-358.

32. Nicholson, R. L., and Kunoh, H. 1995. Early interactions, adhesion, and establishment of the infection court by Erysiphe graminis. Can. J. Bot. 73 (Suppl.):S609-S615.

33. Peries, O. S. 1962. Studies on strawberry mildew caused by Sphaerotheca macularis (Wallr. ex Fries) Jaczewski. Ann. Appl. Biol. 50:211-224.

34. Price, T. V. 1970. Epidemiology and control of powdery mildew (Sphaerotheca fuliginea) on roses. Ann. Appl. Biol. 65:231-248.

35. Quinn, J. A., and Powell, C. C., Jr. 1982. Effects of temperature, light, and relative humidity on powdery mildew of begonia. Phytopathology 72:480-484.

36. Shaw, B., and Hausbeck, M. 1995. Epidemiology of powdery mildew on poinsettia. (Abstr.) Phytopathology 85:1170.

37. Smith, P. H., Foster, E. M., Boyd, L. A., and Brown, J. K. M. 1996. The early development of Erysiphe pisi on Pisum sativum L. Plant Pathol. 45:302-309.

38. Yarwood, C. E. 1957. Powdery mildews. Bot. Rev. 23:235-293.

39. Yarwood, C. E., Sidky, S., Cohen, M., and Santilli, V. 1954. Temperature relations of powdery mildews. Hilgardia 22:603-622. 